\title{
Cumulative Analysis of Port State Control Based on Paris MoU Inspections
}

\author{
Firat Bolat ${ }^{a}$, Selcuk Alpaslan ${ }^{b}$
}

The Port State Control (PSC) was established to control ships entering ports or coastal facilities under its jurisdiction, with inspections by PSC officers aiming to determine whether ships meet safety and pollution prevention requirements and comply with the standards prescribed under the relevant international conventions. Annual reports based on PSC's inspection reports are published under each memorandum of understanding (MoU) regime. The detailed inspection reports within the scope of the PSC, that contain a variety of information about vessels, and the processing and sharing of such information with other regional MoUs are intended to reduce the number of non-conforming practices in the global maritime system. In addition, PSCs publish lists of black, gray and white (BGW) flags, with the classification depending on the number of ship deficiencies and detentions. The classification is an indication of the quality of national flags. When a ship is found to have deficiencies, the inspection

\section{KEY WORDS \\ $\sim$ Port state control \\ $\sim$ Memorandum of understanding \\ $\sim$ Paris MoU \\ $\sim$ United Nations \\ $\sim$ Inspection \\ $\sim$ Detention}

a. Istanbul Technical University, Maritime Faculty, Istanbul, Turkey

e-mail: bolatf@itu.edu.tr

b. Bureau Veritas, Turkey

e-mail: salpaslan@turkloydu.org

doi: 10.7225/toms.v10.n01.019

This work is licensed under (cc) BY

Received on: Jan 4, 2021 / Revised on: Mar 30, 2021 / Accepted on: Apr 13, 2021 / Published: Apr 20, 2021 takes longer, and when the deficiencies are serious, the vessel is detained. Detention periods mean financial losses for the operator and loss of reputation for the flag state. Hence, the lists of black, gray and white flags published by the regional regimes are important in terms of reflecting the reputation of different countries. For these purposes, in this study, the inspections and detentions under the Paris MoU in 2019 have been examined and analyzed by countries and regions. Countries are categorized by UN geographical regions. In particular, the goal of the study was to identify the flag countries of the most frequently inspected and detained ships in 2019, as well as to determine the strategic measures developed by the countries and establish their differences and similarities compared to inspections and detentions in 2018. In addition, the global COVID-19 pandemic in 2019 had a lockdown effect in the maritime domain and a profound effect on society, economy and health worldwide. The result of this study is the prediction of PSC efficiency in terms of the COVID-19 pandemic and the effect of the pandemic on the order of countries in the flag lists.

\section{INTRODUCTION}

The vast majority of the world trade transport is carried out by ships that have a major role in the maritime trade and call to ports of various countries around the world. The vessels should therefore be in a satisfactory condition to ensure safer transport. In this context, the Port State Control (PSC) ensures that ships comply with the international safety, security and marine pollution standards, and that the ships are in good condition (Cariou et al., 2008). At this point, the PSC inspects vessel condition to establish their compliance with the international rules. This control mechanism was put in place by international treaties and inspections are performed in keeping with the Memorandum of Understanding (MoU). 
The Paris MoU, signed by thirteen European countries in 1982, was the first regional PSC regime. Eight other regional PSCs, namely the Tokyo MOU, the Indian Ocean MOU, the Mediterranean MOU, the Acuerdo de Viña del Mar, the Caribbean MOU, the Abuja MOU, the Black Sea MOU, and the Riyadh MOU have subsequently been signed, and the US Coast Guard for the United States region is being developed. These regional MoUs apply international rules and form a second line of defense against non-standard shipping (Perepelkin et al., 2010). Each PSC audit generates an inspection report containing detailed information about deficiencies, including information like the ship's flag, IMO ship number, ship type, construction year and inspection date (Cariou et al., 2008). These individual reports are then compiled into annual reports and published by each MoU regime. In this direction, the regional MoUs want to ensure that non-compliant ships do not trade anywhere in the world by cooperating and exchanging inspection data (Mansell, 2009).

The original objective of the Paris MoU was to inspect $25 \%$ of all foreign merchant ships which enter the ports in its territory, to identify the level of risk. The original inspection regime has since been replaced by a New Inspection Regime (NIR) adopted in 2009 and incorporated into the Paris MoU in 2011. Under NIR, the PSC Committee aims to inspect $100 \%$ of the foreign ships entering its ports. In this new system, the term Ship Risk Profile is used instead of Ship Target Factor. Ship Risk Profile is ship categorization by various risk groups, such as low risk ships or high risk ships, providing that vessels not belonging to any of these groups are considered standard risk ships (Rodríguez \& Piniella, 2012). After the inspection, ships classified as high risk ships are required to be subjected to compulsory expanded inspections every 6 months whenever they enter a Paris MoU port (Yang et al., 2020). In addition, the Paris MoU publishes its Black, Grey, White (BGW) list in its annual report each year. The BGW list shows the full spectrum, from quality flags to poorly performing flags that are considered high or very high risk. The list is based on the total number of inspections and detentions over a 3-year rolling period for flags with at least 30 inspections conducted in the period (Paris MoU, 2020b) .

According to the Paris MoU Annual Report (2019), there were 17,908 inspections, 9,320 inspections that found deficiencies, 526 detentions and 27 refusals of access at the Paris Mou ports in 2019. 41 flag countries are in the white list, 16 flag countries are in the grey list, and 13 flag countries are in the black list. The number of inspections, deficiencies, and detentions in Table 1 are indicative of a continuous decrease. Specifically, there were 17,908 inspections, 39,847 deficiencies, 526 detentions, and 2.94\% of detentions at Paris MoU ports in 2019.

Table 1.

Number of inspections and their results in 2017, 2018, and 2019 (Paris MoU, 2019).

The average number of inspections and results

\begin{tabular}{lllll}
\hline Years & Number of inspections & Number of deficiencies & Number of detentions & Detentions in \% of inspections \\
\hline 2017 & 17925 & 40871 & 695 & $3.88 \%$ \\
\hline 2018 & 17955 & 40428 & 569 & $3.17 \%$ \\
\hline 2019 & 17912 & 39847 & 529 & $2.94 \%$ \\
\hline
\end{tabular}

COVID-19 likely also had an effect on the decreasing numbers of inspections and their results. After the outbreak of COVID-19, the Paris MoU recognized its effect on the international maritime industry. In view of the fact that the COVID-19 is still around and ships continue to experience operational challenges, the Paris MoU adopted temporary guidelines. During the pandemic, surveys, services, and audits are difficult to organize, shipyards close down temporarily. Seafarers have difficulties with certificate extensions, while port restrictions complicate joining ships and repatriation. To prevent these difficulties and ensure the continuity of the global supply chain, the Paris MoU granted an appropriate and proportionate grace period for certificate extensions to mitigate the impact of the COVID-19. In addition, the Paris MoU also took into consideration ILO's information notice on maritime labor issues and COVID-19 in this period
(Paris MoU, 2020a).

To this end, cumulative analysis by country conducted in this study was based on the ratio of the number of inspections and detentions under the Paris MoU. In this context, inspection and detention figures recorded for each country are analyzed individually. In addition, countries have each been assigned to their respective geographical regions, as determined by the United Nations, such as Africa, America, Asia, Europe and Oceania. Cumulative analysis is also presented by geographical regions. In this context, the number of inspections, deficiencies and detentions of ships that were the subjects of 17.912 inspections conducted under the Paris MoU in 2019, by their flag countries have been obtained from the THETIS database of the European Maritime Safety Agency (EMSA) (EMSA THETIS). The goal of this study is to predict ship condition and compliance with the 
international regulations by country in 2019, as well as to create a regional map of these issues. In this context, the study tried to determine the effect of the COVID-19 on ship quality by country.

\section{LITERATURE OVERVIEW}

There are several studies dealing with PSC improvement. Based on statistical analysis, Knapp and Frances have used econometric analysis to identify the differences between multiple PSC regimes (Knapp \& Franses, 2007a, 2007b). Their 2007 suggestion to adjust inspection frequency to the ships' risk profile was adopted by the Paris MoU and resulted in the establishment of NIR in 2011(Bijwaard \& Knapp, 2009; Knapp \& Franses, 2010; Knapp \& van de Velden, 2009). On the other hand, Knapp and Franses (2008) measured the effect of inspections on decreasing the probability of casualty. For that purpose, they used PSC inspection data, casualty data and industry inspections data. They performed a binary logistic regression to determine the correlation between some variables such as ship age, type, flag and casualty. In addition, they also created a time series based on inspection and casualty data. They found that ship type, age and tonnage affected the gravity of the casualty. Detention does not have a significant effect on the probability of casualty. According to descriptive statistics, South and North China Sea, the Arabian Gulf and the Indian Ocean, the West African Coast and the Mediterranean Sea and Black Sea are high risk areas for casualties. Contrary to expectations, the strongest effect of port state control inspection on the probability of casualty was identified in the South American Region, the Indian Ocean Region and in Australia, and not in the European or North American region.

Li and Zheng (2008) have researched the effectiveness of the PSC and proposed the methods for the selection of vessels for inspection by the regional PSC. Bang and Jang (2012) have examined whether the regional PSC MOUs are effective in addressing the problem of substandard ships by looking at their membership, legal authority, financial capacity, structure, substantive scope, and action plans and policies. They have presented the genesis of each MoU. According to results, the Paris and Tokyo MOUs are the most successful regional MOUs, that have high numbers of economically strong states, cover densely traveled vessel areas, have experienced vessel pollution disasters, and have self-initiated regional PSC MOUs. Li et al (2014) have explored the safety index. They found that certain variables, such as vessel age, size, type, classification society and navigation zone are the key parameters for a vessel's safety index. They have arrived at the conclusion that vessel registers are a particularly important factor for vessel safety index. Vessels registered in Japan, China, the Netherlands, India, Mexico, Brazil, Australia, Taiwan China, Sweden, Morocco, Belgium, South Africa and Ireland have higher safety levels, while on the other hand, safety levels of vessels registered in Panama, the United States, Russia, Norway, Malta, Greece, Italy, Bahamas, Spain, Turkey, Honduras and Canada are lower.

Though there general analyses of the influence of the professional profile of PSC inspectors and the results of inspections can be found in available literature, (Knapp \& Franses, 2007a; Ravira \& Piniella, 2016), Wu et al (2014) have given some suggestions for the effective evaluation of fire drills in response to the PSC's new inspections regime. They have analyzed PSC inspections from specific aspects. Ravira and Piniella (Ravira \& Piniella, 2016) have studied the effect of the professional background of PSC officers on inspection results by conducting a case study of the Spanish Maritime Administration. They have found that the professional background of PSC officers, as well as the absence of an inspection application procedure have a significant effect on inspection outcome.

A number of studies have covered the issue of flag performance under different MoUs (Bolat, 2019; Chen et al., 2017; Corres \& Pallis, 2008). Bolat (2019) investigated how ships sailing under Turkish flag fared in inspections conducted under the Tokyo MoU, that includes port states in the Asia-Pacific region, identified their deficiencies, and proposed measures that could be taken by the Republic of Turkey, as their flag state, to remedy the issue. Other authors have stated that the performance of the flag state has direct implications for the targeting factor of a vessel, i.e. for the probability that a ship will be singled out as a candidate for priority PSC inspections. Poorly performing flags are subject to a greater number of PSC inspections, whereas well performing ones are subject to a less stringent inspection regime (Corres \& Pallis, 2008).

Several studies have looked into the effect of COVID-19 on the maritime sector (Akyurek \& Bolat, 2020; Chen et al., 2017; Doumbia-Henry, 2020; Fuwape et al., 2021; Rodríguez \& Piniella, 2012; Wu et al., 2014). However, Akyurek and Bolat (2020) have addressed the PSC issue directly in connection with the Covid-19 outbreak. They conducted a comparative analysis of the total number of inspections performed in 2015-2020 to establish the effect of the pandemic on ship inspection numbers. They then conducted an Entropy-based Grey Relational Analysis, using inspection results to assess variations in PSC results attributable to the COVID-19. The results suggest, that in spite of the dramatically decrease in the number of Paris MoU inspections, the PSC is still effective with respect to the detention rate of the ships inspected. However, the Grey Analysis has found a change in PSC Officers' shortcomings and detention orders.

Compared with existing research, this paper has two distinctive features. The first is having the performance of all countries worldwide examined within the scope of the Paris MoU by comparing the number of deficiencies and detentions 
relative to the number of inspections in terms of COVID-19. The second is the presentation of the performance map of regions, as determined by the United Nations, under the Paris MoU.

\section{METHOD}

In this paper, the descriptive statistical method was used to determine the quality of countries in terms of compliance with international maritime rules. Its objective is to view each country in isolation in terms of Paris MoU inspections and their results and create a map of regions as defined by the United Nations. The United Nations divide the world into geographical regions such as Africa, the Americas, Asia, Europe and Oceania (United Nations, 2019). Cumulative analysis and the ratio of the number of vessel inspections and detentions by the Paris MoU by country and by region are examined.

Descriptive results have been obtained from the observation values obtained from the THETIS database (EMSA THETIS). The data relate to 2019 Paris MoU inspections and their results for countries from around the world. A total of 17,908 inspections were conducted, 9,320 inspections found deficiencies, 526 vessels were detained and 27 banned from the Paris MoU ports in 2019. 41 flag countries were placed on the white list, 16 on the grey list, and 13 on the black list in 2019. The objective was to present Paris MoU inspections of ships from around the world and the results of such inspections for each country separately, and forge regional identities. In addition, a closer look at inspection distribution and results for each country included in the BGW flag list might reveal the reasons for delegating particular countries to a specific list.

XLSTAT and Excel software programs were used to arrive at a better understanding of the distribution of Paris MoU inspections and their results for each country (XLSTAT). For this purpose, a huge number of data were summarized, organized and classified depending on the number of inspections conducted by the Paris $\mathrm{MoU}$, the number of detentions and inspection day, for each flag. The countries are categorized by geographical regions as used by the United Nations. Using the information obtained, a statistical improvement in classification was achieved.

\section{PARIS MOU PORT STATE CONTROL ANALYSIS BY COUNTRY}

Figure 1 illustrates the number of vessel detentions under the Paris MoU in 2019. Figure 1 clearly shows that countries with the greatest number of detained vessels are Panama, Liberia, Malta, and the Marshall Islands. However, they can not be said to have a high detention ratio, since the number of inspections is also a critical factor for determining the detention/inspection ratio. Table 2 shows the inspection/detention ratio of countries with the highest number of detentions, while Table 3 shows the countries with the highest detention/inspection ratio. According to these tables, Panama has the highest number of inspections (2026), the highest number of detentions (92), and a medium detention/inspection ratio (0.0454). On the other hand, Nigeria and Samoa have the minimum number of inspections (1), the minimum number of detentions (1), and the highest detention/ inspection ratios (1). In the tables, countries are ordered depending on their detention/inspection ratio.

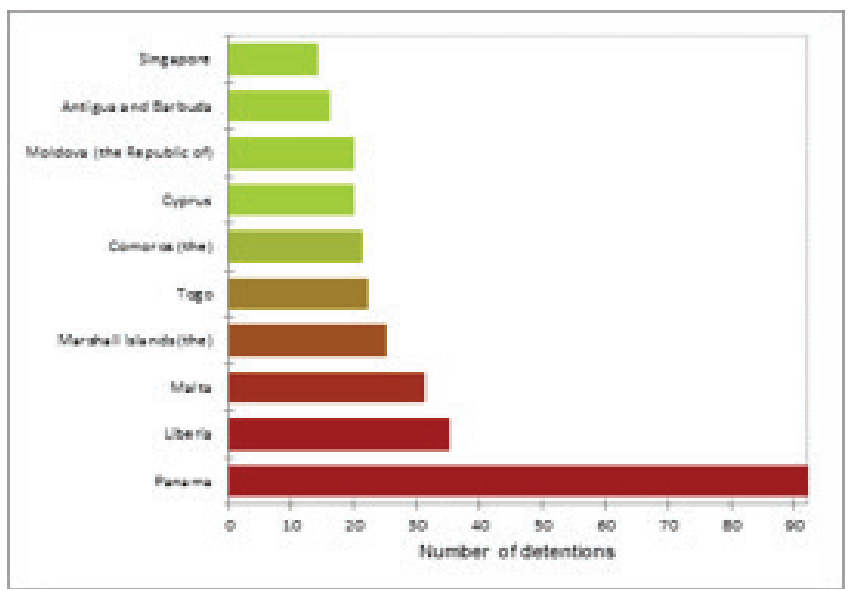

Figure 1.

The highest number of detentions by flag state under the Paris MoU in 2019.

In Figure 2, the number of vessel detentions for countries having the highest detention numbers was inspected daily and recorded cumulatively. The $\mathrm{x}$-axis of the figure represents the number of days vessels of a particular country have been inspected. For instance, Malta flag vessels were inspected between 150 and 200 out of 365 days.

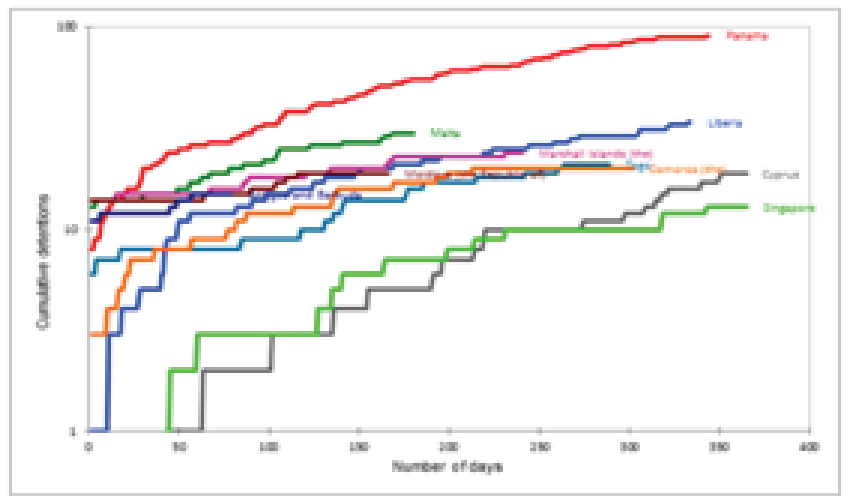

Figure 2.

Cumulative vessel detentions by country under the Paris MoU in 2019. 
Table 2.

Countries with the highest detention numbers.

\begin{tabular}{lllll} 
No & Country & $\begin{array}{l}\text { Ratio } \\
\text { (Detentions/inspections) }\end{array}$ & Total inspections & Total detentions \\
\hline 1 & Panama & 0.04541 & 2,026 & 92 \\
\hline 2 & Liberia & 0.023777 & 1,472 & 35 \\
\hline 3 & Malta & 0.020571 & 1,507 & 31 \\
\hline 4 & Marshall Islands (the) & 0.015944 & 1,568 & 25 \\
\hline 5 & Togo & 0.145695 & 151 & 22 \\
\hline 6 & Comoros (the) & 0.165354 & 127 & 21 \\
\hline 7 & Cyprus & 0.027548 & 726 & 20 \\
\hline 8 & Moldova (the Republic of) & 0.152672 & 131 & 20 \\
\hline 9 & Antigua and Barbuda & 0.022409 & 714 & 16 \\
\hline 10 & Singapore & 0.020115 & 696 & 14 \\
\hline
\end{tabular}

\section{Table 3.}

Countries with the highest detention/inspection ratio.

\begin{tabular}{lllll} 
No & Country & $\begin{array}{l}\text { Ratio } \\
\text { (Detentions/inspections) }\end{array}$ & Total inspections & Total detentions \\
\hline 1 & Nigeria & 1 & 1 & 1 \\
\hline 2 & Samoa & 1 & 1 & 1 \\
\hline 3 & Cameroon & 0.277778 & 18 & 5 \\
\hline 4 & Qatar & 0.25 & 8 & 2 \\
\hline 5 & Switzerland & 0.227273 & 22 & 5 \\
\hline 6 & Albania & 0.214286 & 28 & 1 \\
\hline 7 & Bangladesh & 0.166667 & 6 & 1 \\
\hline 8 & Dominican Republic & 0.166667 & 6 & 3 \\
\hline 9 & Egypt & 0.166667 & 18 & 12 \\
\hline 10 & Tunisia & 0.166667 & & 2 \\
\hline
\end{tabular}

\section{PARIS MOU PORT STATE CONTROL ANALYSIS BY REGION}

Paris MoU PSCs are examined and analyzed by flag countries of inspected vessels. The analysis followed the geographical division used by the United Nations. The regions are Africa, the Americas, Asia, Europe and Oceania.

\subsection{Africa}

\subsubsection{Sub-Saharan}

Figure 3 shows the number of detentions at Paris MoU ports in 2019 by Sub-Saharan African country. Although the Liberian flag seems to have the highest number of detentions, Table 4 shows that Liberia does not have the highest detention/ inspection ratio as it has the highest number of inspections. 
Table 4 shows that only one vessel sailing under the Nigerian flag was inspected by the Paris MoU and that the vessel was detained. Nigeria, Cameron and the Comoros have the highest detention/inspection ratio in Sub-Saharan Africa. Although Nigeria has the highest detention/inspection ratio, only one inspection of its ships was conducted. The Liberian flag has the highest number of inspections and detentions. The results for this region are one-hundred-and-three detentions out of one-thousand-ninety-two inspections conducted by the Paris MoU. The overall ratio for this region is 0.05 . Mauritius, Ethiopia and Cabo Verde flags have no detention record.

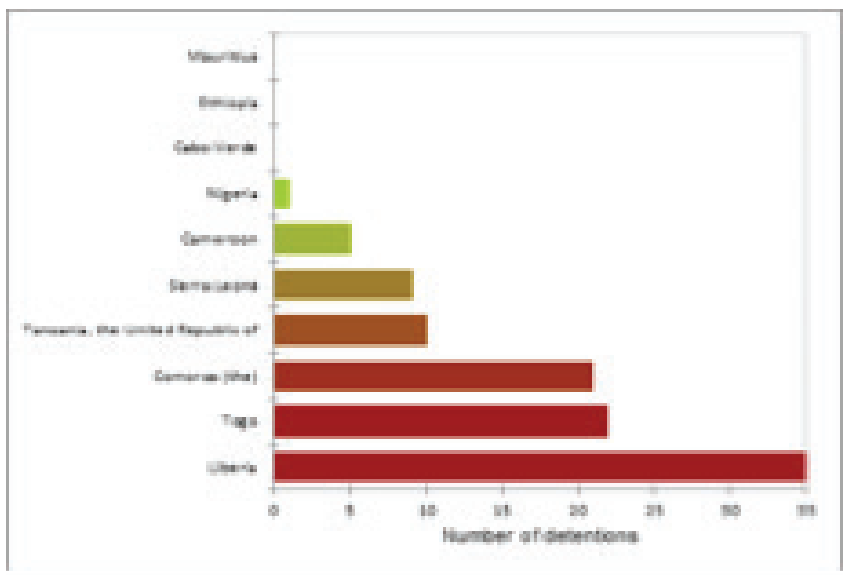

Figure 4 shows the logarithmic cumulative detentions for Sub-Saharan Africa countries at Paris MoU ports in 2019. The daily number of cumulative detentions can show detention periods of these countries. Vessels sailing under the flags of Liberia, Togo, the Comoros and Tanzania are inspected and detained approximately every day. Vessels flying the Cameron flag were detained in the second half of the year.

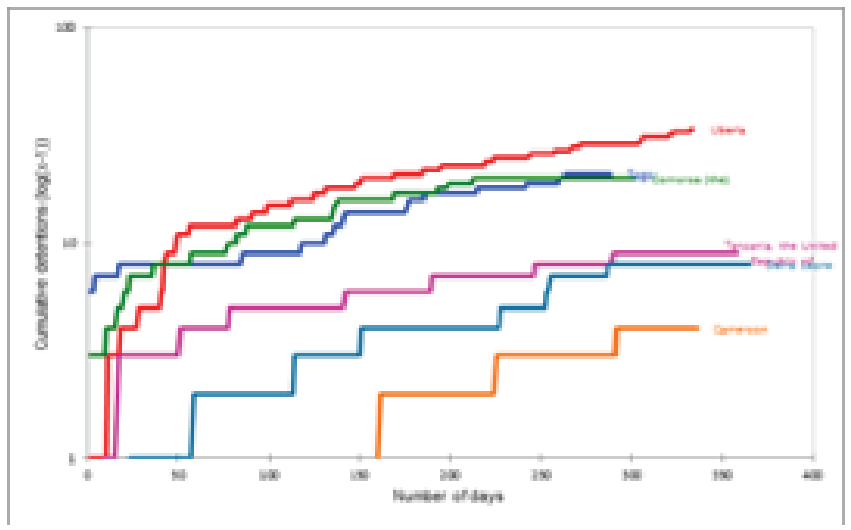

Figure 4.

Cumulative detentions for Sub-Saharan Africa under the Paris MoU in 2019

Figure 3.

The highest detention numbers by Sub-Saharan African country under the Paris MoU in 2019.

Table 4.

The Sub-Saharan Africa regions with the highest detention/inspection ratios.

\begin{tabular}{lllll} 
No & Country & $\begin{array}{l}\text { Ratio } \\
\text { (Detentions/inspections) }\end{array}$ & Total inspections & Total detentions \\
\hline 1 & Nigeria & 1 & 1 & 1 \\
\hline 2 & Cameroon & 0.28 & 18 & 5 \\
\hline 3 & Comoros (the) & 0.17 & 127 & 21 \\
\hline 4 & Togo & 0.15 & 151 & 22 \\
\hline 5 & Tanzania, the United Republic of & 0.11 & 92 & 10 \\
\hline 6 & Sierra Leone & 0.07 & 124 & 9 \\
\hline 7 & Liberia & 0.02 & 1472 & 35 \\
\hline 8 & Cabo Verde & 0 & 1 & 0 \\
\hline 9 & Ethiopia & 0 & 1 & 0 \\
\hline 10 & Mauritius & 0 & 5 & 0
\end{tabular}




\subsubsection{Northern Africa}

Figure 5 shows the number of detentions at Paris MoU ports in 2019 by Northern African country. Egypt has the highest number of detained vessels. Whereas some Tunisian and Algerian vessels have been detained under the Paris MoU, Morocco and Libya have no detention records.

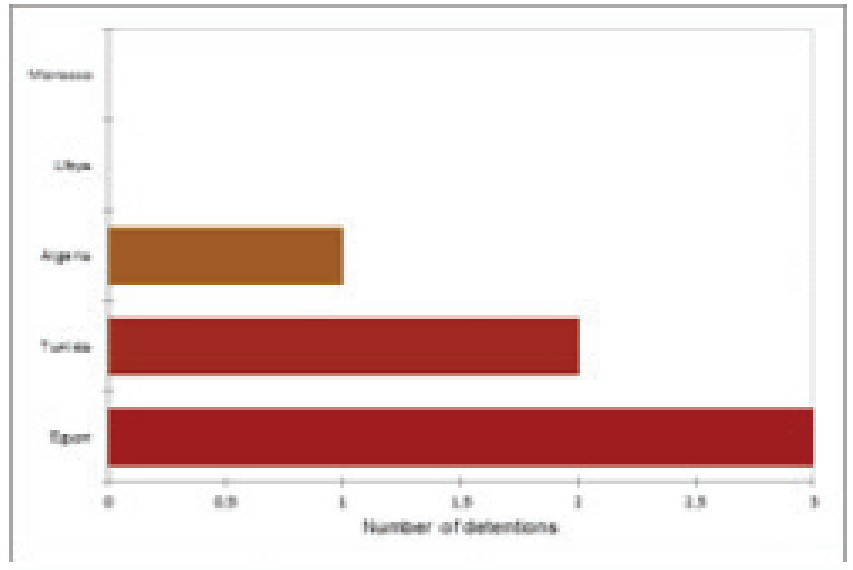

Figure 5.

The highest detention numbers by Northern African country under the Paris MoU in 2019.

Figure 6 shows the logarithmic cumulative detentions for Northern African countries under the Paris MoU in 2019. There are no detention records for the first half of the year. Only three out of five countries had their ships detained in 2019. When the region of Northern Africa is compared with other regions, it has lower inspection and detention numbers, with only 6 detentions and 85 inspections.

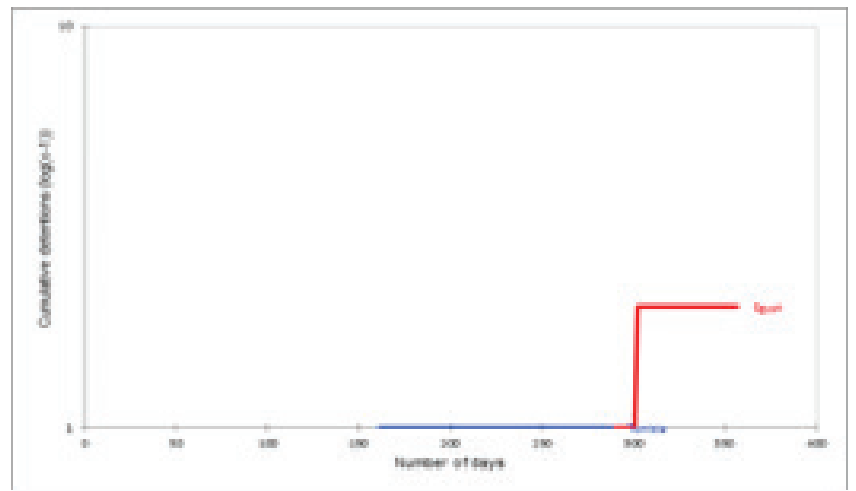

Figure 6.

Cumulative detentions for Northern Africa under the Paris MoU in 2019

According to Table 5, in spite of the equal number of inspections of vessels sailing under Moroccan and Egyptian flags, the Egyptian ratio is higher than Morocco's because Egypt had detentions. Morocco and Libya had the lowest number of detentions, i.e. zero detentions. Algeria has the lowest ratio among flags with detentions. This region had six detentions out of 85 inspections conducted under the Paris MoU. The overall ratio for this region is 0.071 .

Table 5.

Northern Africa regions with the highest detention/inspection ratios.

\begin{tabular}{lllll} 
No & Country & $\begin{array}{l}\text { Ratio } \\
\text { (Detentions/inspections) }\end{array}$ & Total inspections & Total detentions \\
\hline 1 & Egypt & 0.17 & 18 & 3 \\
\hline 2 & Tunisia & 0.17 & 12 & 2 \\
\hline 3 & Algeria & 0.04 & 27 & 1 \\
\hline 4 & Libya & 0 & 10 & 0 \\
\hline 5 & Morocco & 0 & 18 & 0 \\
\hline
\end{tabular}

\subsection{America}

\subsubsection{Latin America and the Caribbean}

Figure 7 and Figure 8 show the number of detentions and logarithmic cumulative detentions at Paris MoU ports in 2019, by
Latin American and Caribbean country. Panama has the highest number of detentions that far outstrips detention numbers of other countries. Other countries with the highest detention rates are Antigua and Barbuda and Saint Vincent and the Grenadines. Jamaica, the Dominican Republic and the Cayman Islands have the lowest number of detained vessels. 


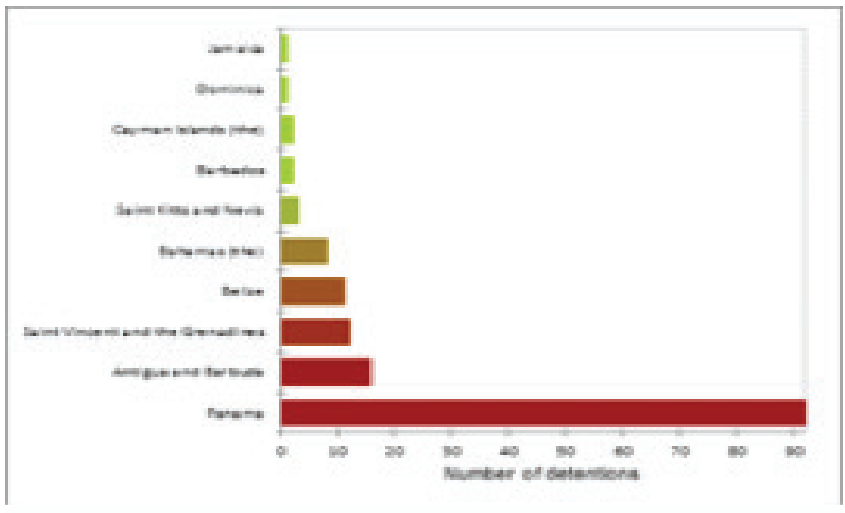

Figure 7.

The highest detention numbers by Latin American and Caribbean country in 2019.

Figure 8 shows that Panama flag vessels are inspected every day. The Panama flag has the highest number of detentions and inspections. Antigua and Barbuda flags were inspected in the first third of the year. Saint Kitts and Nevis flag vice versa.

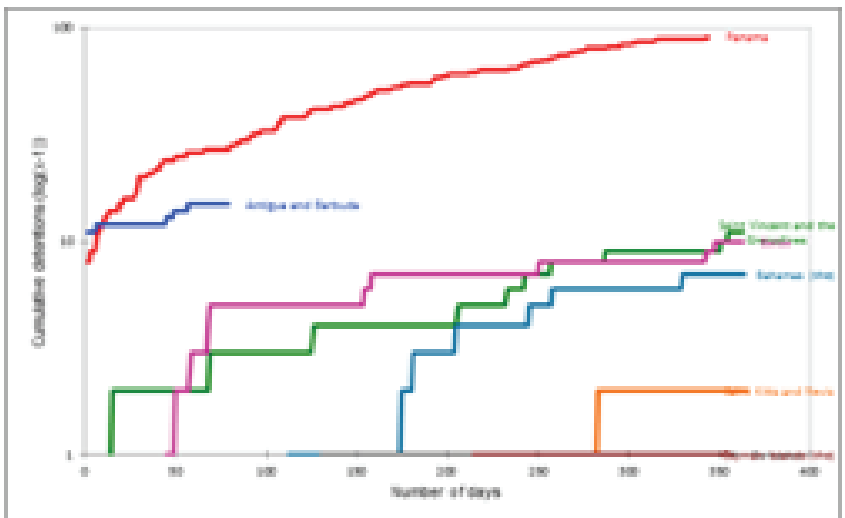

Figure 8.

Cumulative detentions for Latin America and the Caribbean in 2019.

According to Table 6, the Dominican flag has the highest inspection/detention ratio and the lowest number of inspections, with only 6 inspections. The Jamaican flag is quite similar. The Bahamas have the third highest number of inspections. However only 8 vessels were detained in 676 inspections. The Cayman Islands, Barbados and Bahamas flags have the lowest detention ratio of 0.01 .

Table 6.

Latin American and Caribbean regions with the highest detention/inspection ratios.

\begin{tabular}{lllll} 
No & Country & $\begin{array}{l}\text { Ratio } \\
\text { (Detentions/inspections) }\end{array}$ & Total inspections & Total detentions \\
\hline 1 & Dominican Republic & 0.17 & 6 & 1 \\
\hline 2 & Jamaica & 0.14 & 7 & 1 \\
\hline 3 & Belize & 0.11 & 99 & 11 \\
\hline 4 & Saint Vincent and the & 0.09 & 141 & 12 \\
\hline 5 & Grenadines & & 33 & 3 \\
\hline 6 & Saint Kitts and Nevis & 0.09 & 2026 & 92 \\
\hline 7 & Panama & 0.05 & 714 & 16 \\
\hline 8 & Antigua and Barbuda & 0.02 & 676 & 8 \\
\hline 9 & Bahamas (the) & 0.01 & 143 & 2 \\
\hline 10 & Barbados & 0.01 & 148 & 2 \\
\hline
\end{tabular}

\subsubsection{Northern America}

According to Table 7, no detentions were recorded for this region in the Paris MoU PSC inspections. The total of 77 inspections were carried out under the Paris MoU. The USA flag has no inspections. Canadian and Bermudan flags have no detentions. 
Table 7.

Northern America regions with the highest detention/inspection ratios.

\begin{tabular}{lllll} 
No & Country & $\begin{array}{l}\text { Ratio } \\
\text { (Detentions/inspections) }\end{array}$ & Total inspections & Total detentions \\
\hline 1 & Bermuda & 0 & 72 & 0 \\
\hline 2 & Canada & 0 & 5 & 0 \\
\hline 3 & $\begin{array}{l}\text { United States of America } \\
\text { (the) }\end{array}$ & 0 & 0 & 0 \\
\hline
\end{tabular}

\subsection{Asia}

\subsubsection{Central Asia}

According to Table 8, no detentions were recorded for this region in the Paris MoU PSC inspections

Table 8.

Central Asian regions with the highest detention/inspection ratios.

\begin{tabular}{lllll} 
No & Country & $\begin{array}{l}\text { Ratio } \\
\text { (Detentions/inspections) }\end{array}$ & Total inspections & Total detentions \\
\hline 1 & Kazakhstan & 0 & 14 & 0 \\
\hline 2 & Turkmenistan & 0 & 3 & 0 \\
\hline
\end{tabular}

\subsubsection{Eastern Asia}

Figure 9 and Figure 10 show the number of detentions and logarithmic cumulative detentions at Paris MoU ports in 2019, by Eastern Asian country. Singapore has the highest number of detentions. The flags of Hong Kong (China), Mongolia, China, the Philippines and Korea have detentions. Indonesia, Japan, Malaysia and Taiwan (Province of China) have no detentions.

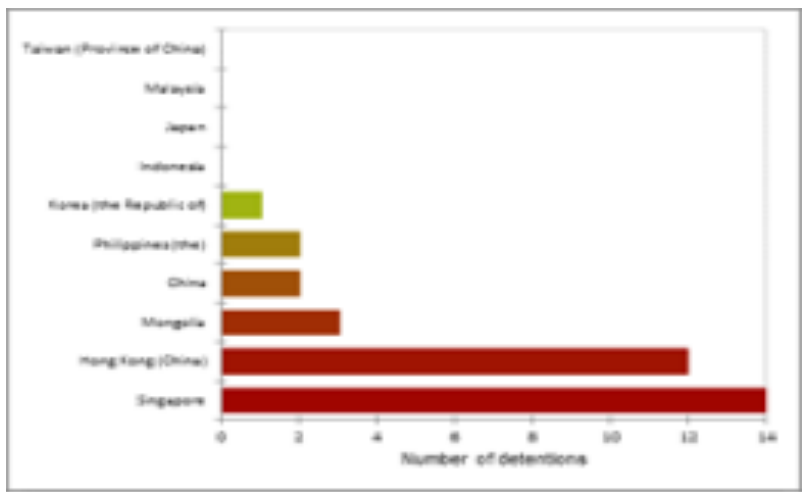

Figure 9.

The highest detention numbers by Eastern Asian country in 2019.
According to Figure 9, Singapore and Hong Kong flags have been inspected almost every day, detentions spread throughout the year. Other flags, with the exception of Mongolia, China, the Philippines and Korea had a lower number of inspections and no detentions. Detentions of ships sailing under Mongolian flag have been increased between day 50 and day 100 .

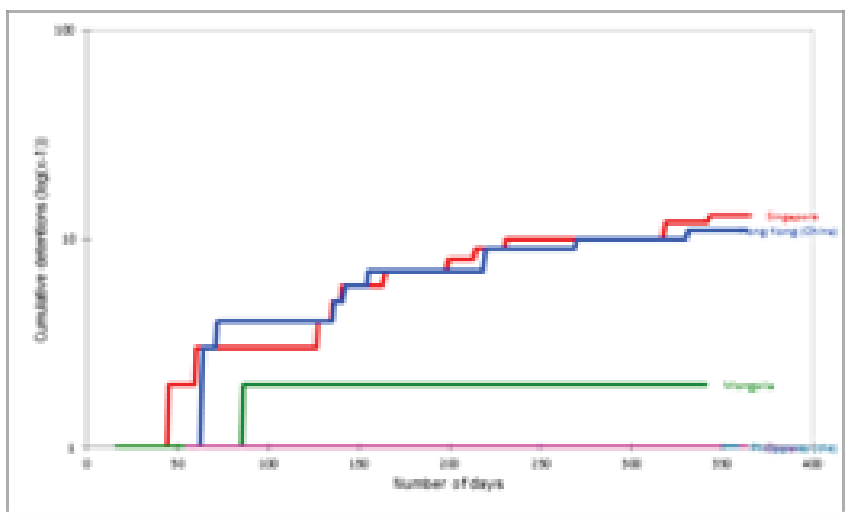

Figure 10.

Cumulative detentions for Eastern Asia in 2019. 
According to Table 9, ships flying the flags of Singapore, Hong Kong (China) and Mongolia have the highest detention figures. Mongolia has the highest detention/inspection ratio. The
Singapore flag has the highest number of inspections. Indonesia, Japan, Malaysia and Taiwan (Province of China) have the lowest ratios, as they have had no detentions.

Table 9.

Eastern Asia regions with the highest detention/inspection ratios.

\begin{tabular}{|c|c|c|c|c|}
\hline No & Country & $\begin{array}{l}\text { Ratio } \\
\text { (Detentions/inspections) }\end{array}$ & Total inspections & Total detentions \\
\hline 1 & Mongolia & 0,13 & 23 & 3 \\
\hline 2 & China & 0,05 & 44 & 2 \\
\hline 3 & Philippines (the) & 0,04 & 49 & 2 \\
\hline 4 & Korea (the Republic of) & 0,04 & 24 & 1 \\
\hline 5 & Singapore & 0,02 & 696 & 14 \\
\hline 6 & Hong Kong (China) & 0,02 & 642 & 12 \\
\hline 7 & Indonesia & 0 & 1 & 0 \\
\hline 8 & Japan & 0 & 64 & 0 \\
\hline 9 & Malaysia & 0 & 10 & 0 \\
\hline 10 & Taiwan (Province of China) & 0 & 7 & 0 \\
\hline
\end{tabular}

\subsubsection{Southern Asia}

Figure 11 shows the number of detentions and logarithmic cumulative detentions at Paris MoU ports in 2019, by Southern Asian country. The graph clearly shows that Bangladesh and Iran have detention records. They have only one detention each. Other flags from the Southern Asia region had no detentions.
According to Table 10, the Bangladesh flag has the highest detention/inspection ratio. Since India, Pakistan and Sri Lanka have no detention record, their detention/inspection ratio is zero. Iran has the lowest detention/inspection ratio among flags that have detentions.

\section{Table 10.}

Eastern Asia regions with the highest detention/inspection ratios.

\begin{tabular}{|c|c|c|c|c|}
\hline No & Country & $\begin{array}{l}\text { Ratio } \\
\text { (Detentions/inspections) }\end{array}$ & Total inspections & Total detentions \\
\hline 1 & Bangladesh & 0.17 & 6 & 1 \\
\hline 2 & Iran (Islamic Republic of) & 0.03 & 35 & 1 \\
\hline 3 & India & 0 & 15 & 0 \\
\hline 4 & Pakistan & 0 & 1 & 0 \\
\hline 5 & Sri Lanka & 0 & 6 & 0 \\
\hline
\end{tabular}




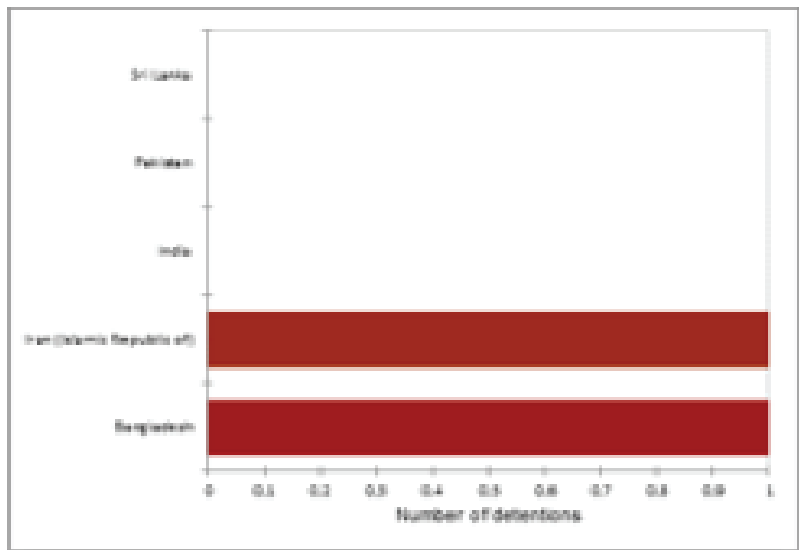

Figure 11.

The highest detention numbers by Southern Asian country in 2019.

\subsubsection{Western Asia}

Figure 12 and Figure 13 show the number of detentions and logarithmic cumulative detentions at Paris MoU ports in 2019, by Western Asia country. Cyprus, Turkey, Lebanon and Qatar have detention records. Cyprus had the highest number of detentions. Saudi Arabia, Kuwait, Jordan, Israel, Georgia and Azerbaijan had no detentions under the Paris MoU.

According to Figure 13, vessels flying the Cyprus flag were inspected almost every day, with detentions spread throughout the year. Other flags, with the exception of the Turkish flag, were not subjected to as many inspections in 2019. The number of detentions of ships sailing under the Turkish flag increased between day 280 and day 360. As Qatar and Lebanon had only 2 detentions, our logarithmic cumulative detention graph could not show the part of the year when their detention numbers increased.

The detentions/inspections ratios in Table 11 show that Qatar flag took the lead with the highest ratio of 0.25 . Though the Lebanon flag has the highest number of detentions, it has the second highest detentions/inspections ratio. Saudi Arabia,

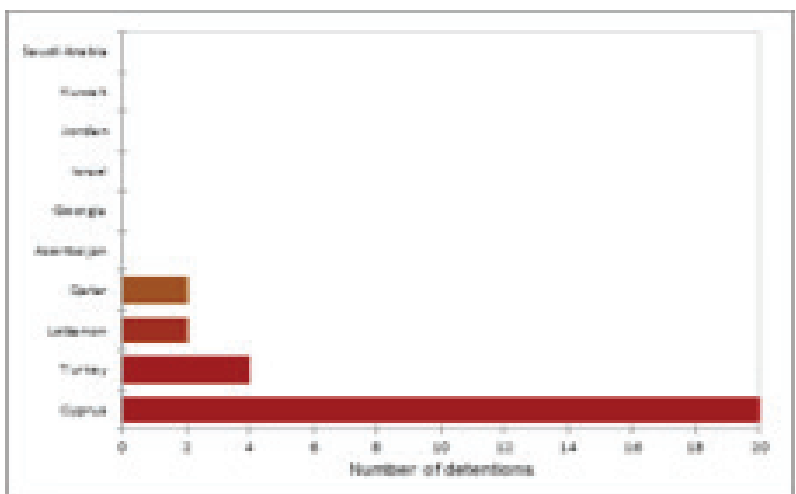

Figure 12

The highest detention numbers by Western Asian country in 2019.

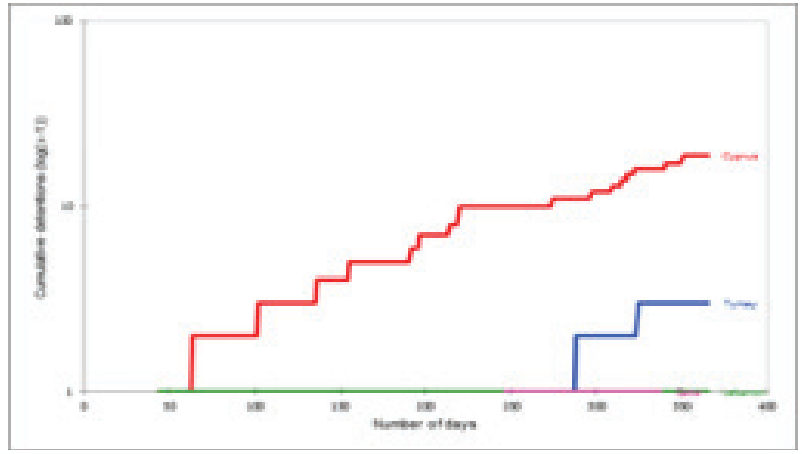

Figure 13.

Cumulative detentions for Western Asia in 2019.

Israel, Kuwait, Georgia and Jordan flags had inspections and are listed in a descending order, from countries with the highest number of inspections with zero detentions to countries with the lowest number of inspections with zero detentions. Turkey has the highest performing flag among Western Asian flags with detentions. 
Table 11.

Western Asian regions with the highest detention/inspection ratios.

\begin{tabular}{lllll} 
No & Country & $\begin{array}{l}\text { Ratio } \\
\text { (Detentions/inspections) }\end{array}$ & Total inspections & Total detentions \\
\hline 1 & Qatar & 0.25 & 8 & 2 \\
\hline 2 & Lebanon & 0.08 & 26 & 2 \\
\hline 3 & Cyprus & 0.03 & 726 & 20 \\
\hline 4 & Turkey & 0.02 & 252 & 0 \\
\hline 5 & Azerbaijan & 0 & 24 & 0 \\
\hline 6 & Georgia & 0 & 4 & 0 \\
\hline 7 & Israel & 0 & 8 & 0 \\
\hline 8 & Jordan & 0 & 1 & 0 \\
\hline 9 & Kuwait & 0 & 5 & 16 \\
\hline 10 & Saudi Arabia & 0 & & 0 \\
\hline & & & & 0 \\
\end{tabular}

\subsection{Europe}

\subsubsection{Eastern Europe}

Figure 14 and Figure 15 show the number of detentions and logarithmic cumulative detentions at Paris MoU ports in 2019, by Eastern European country. Countries that had their vessels detained are Moldova, the Russian Federation, Ukraine, Poland and Bulgaria. The Moldova flag had the highest number of detained vessels. Romania has no detention record.

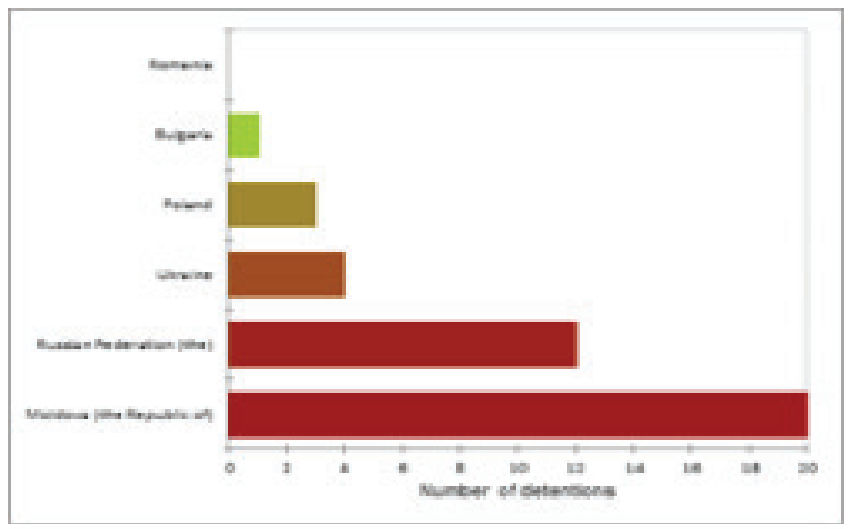

Figure 14.

The highest detention numbers by Eastern European country in 2019.
According to Figure 15, Moldova flag vessels had no detentions in the second half of the year. Russian Federation flag detentions are spread throughout the year. Ukrainian and Polish flag detentions generally occurred in the first half of the year.

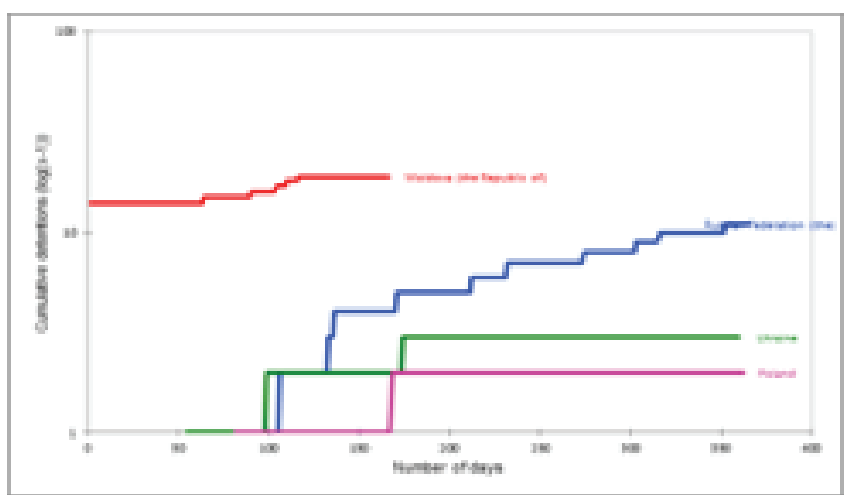

Figure 15.

Cumulative detentions for Eastern Europe in 2019.

Table 12 shows that Moldova has the highest detention/ inspection ratio. In spite of the Russian Federation's flag being subjected to the highest number of inspections, it has the best detention ratio among flags that have had their vessels detained. The Romanian flag was subjected to only one inspection in 2019. 
Table 12.

Eastern Europe regions with the highest detention/inspection ratios.

\begin{tabular}{|c|c|c|c|c|}
\hline No & Country & $\begin{array}{l}\text { Ratio } \\
\text { (Detentions/inspections) }\end{array}$ & Total inspections & Total detentions \\
\hline 1 & Moldova (the Republic of) & 0.15 & 131 & 20 \\
\hline 2 & Bulgaria & 0.13 & 8 & 1 \\
\hline 3 & Ukraine & 0.12 & 34 & 4 \\
\hline 4 & Poland & 0.1 & 29 & 3 \\
\hline 5 & Russian Federation (the) & 0.03 & 425 & 12 \\
\hline 6 & Romania & 0 & 1 & 0 \\
\hline
\end{tabular}

\subsubsection{Northern Europe}

Figure 16 and Figure 17 show the number of detentions and logarithmic cumulative detentions at Paris MoU ports in 2019, by Northern European country. The flag of the United Kingdom of Great Britain and Northern Ireland had the highest number of detentions of all Northern European flags. Iceland has no detention record. A total of 28 detentions have been recorded. The flags of the Isle of Man and Norway share the position of the second most detained flag. Irish and Estonian flags had only one detention each.

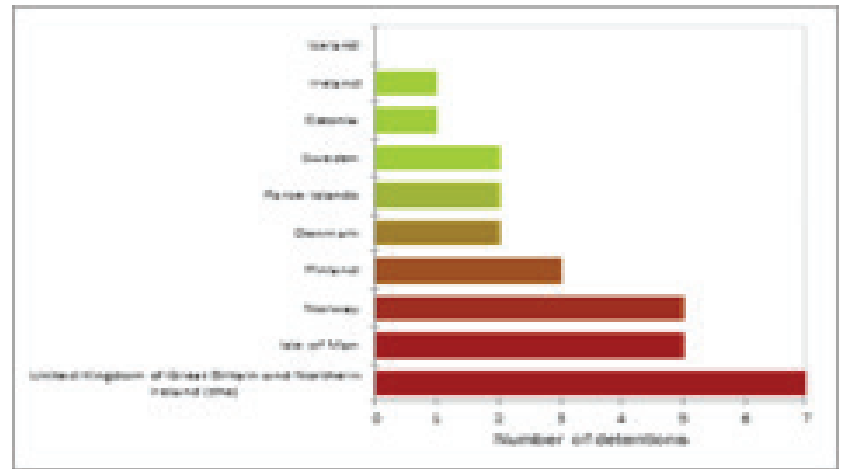

Figure 16.

The highest detention numbers by Northern European country in 2019.
Looking at the cumulative distribution in Figure 17, the detentions of vessels flying the flag of the United Kingdom of Great Britain and Northern Ireland have been spread throughout the year. The Isle of Man flag detentions had increased between day 300 and day 360 . Norwegian flag detentions occurred in the first half of the year. Irish, Estonian and Swedish flags had less than 3 detentions.

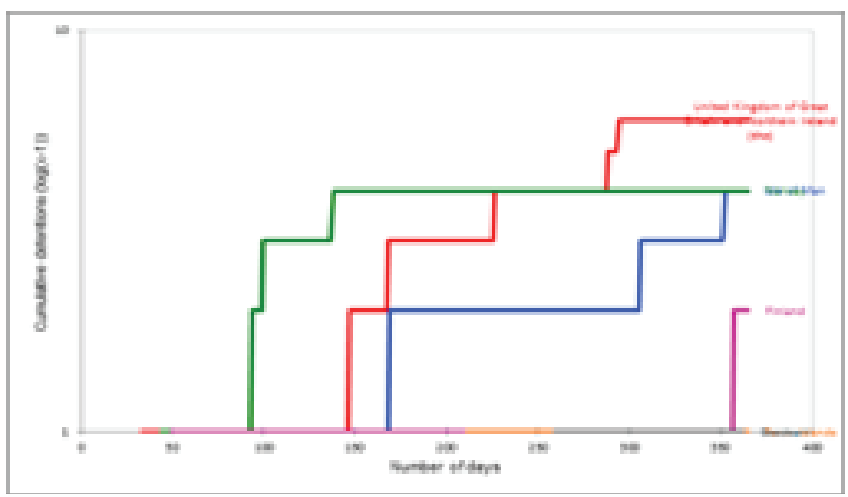

Figure 17.

Cumulative detentions for Northern Europe in 2019.

According to Table 13, the Estonian flag has the highest detention/inspection ratio, in spite of having only one detention. Vessels flying the Norwegian flag had the highest number of inspections, 5 of which resulted in detentions. In spite of having the highest number of detentions, the flag of the United Kingdom of Great Britain and Northern Ireland did not have the highest detention/inspection ratio. 
Table 13.

Northern Europe regions with the highest detention/inspection ratios.

\begin{tabular}{lllll} 
No & Country & $\begin{array}{l}\text { Ratio } \\
\text { (Detentions/inspections) }\end{array}$ & Total inspections & Total detentions \\
\hline 1 & Estonia & 0.03 & 31 & 1 \\
\hline 2 & $\begin{array}{l}\text { United Kingdom of Great Britain } \\
\text { and Northern Ireland }\end{array}$ & 0.02 & 397 & 7 \\
\hline 3 & Isle of Man & 0.02 & 204 & 5 \\
\hline 4 & Finland & 0.02 & 158 & 3 \\
\hline 5 & Faroe Islands & 0.02 & 91 & 2 \\
\hline 6 & Sweden & 0.02 & 112 & 2 \\
\hline 7 & Ireland & 0.02 & 53 & 1 \\
\hline 8 & Norway & 0.01 & 597 & 5 \\
\hline 9 & Denmark & 0 & 469 & 2 \\
\hline 10 & Iceland & 0 & 1 & 0 \\
\hline & & & & 2 \\
\end{tabular}

\subsubsection{Southern Europe}

Figure 18 and Figure 19 show the number of detentions and logarithmic cumulative detentions at Paris MoU ports in 2019, by Southern European country. The number of detentions of vessels sailing under the Maltese flag far outstrips that of the other Southern European flags. Slovenian, Montenegrin and Croatian flags have no detention records. The flags of Portugal, Gibraltar and Italy follow Malta in the number of detentions in that order. Albanian, Greek and Spanish flags have less than 5 detentions.

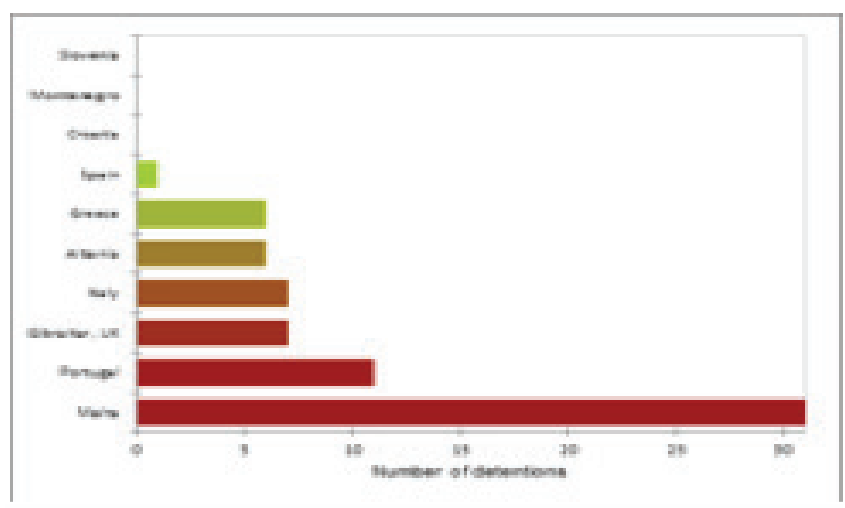

Figure 18.

The highest detention numbers by Southern Europe country in 2019.
Looking at the cumulative distribution in Figure 19, the detentions of vessels sailing under the Maltese flag occurred in the first half of the year. The vast majority of detentions of ships flying the Portuguese, Gibraltar, Italian, Albanian and Greek flags occurred in the second half of the year. Among these flags, nearly all detentions of Greek and Albanian flags occurred in the last quarter of the year.

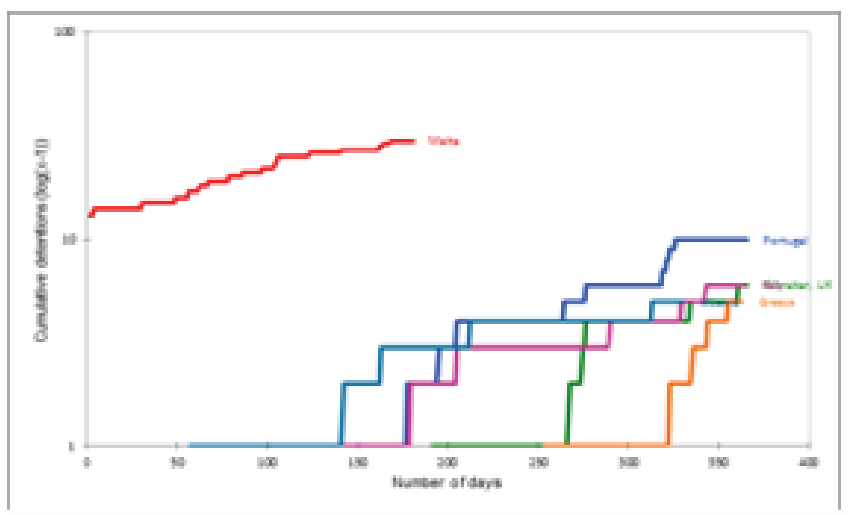

Figure 19.

Cumulative detentions for Southern Europe in 2019.

According to Table 14, the Albanian detention/inspection ratio far outstrips that of other flags. Approximately every fifth inspection resulted in detention. Although ships with the Maltese flag were frequently inspected, this is a high performing flag, with an excellent detention/inspection ratio. Maltese, Italian, Greek and Spanish flags had the same detention/inspection ratio. 
Table 14.

Southern European regions with the highest detention/inspection ratios.

\begin{tabular}{lllll} 
No & Country & $\begin{array}{l}\text { Ratio } \\
\text { (Detentions/Inspections) }\end{array}$ & Total inspections & Total detentions \\
\hline 1 & Albania & 0.21 & 28 & 6 \\
\hline 2 & Portugal & 0.03 & 402 & 11 \\
\hline 3 & Gibraltar, UK & 0.03 & 226 & 7 \\
\hline 4 & Malta & 0.02 & 1507 & 31 \\
\hline 5 & Italy & 0.02 & 348 & 7 \\
\hline 6 & Greece & 0.02 & 250 & 6 \\
\hline 7 & Spain & 0.02 & 55 & 0 \\
\hline 8 & Croatia & 0 & 34 & 0 \\
\hline 9 & Montenegro & 0 & 3 & 0 \\
\hline 10 & Slovenia & 0 & 3 & 0 \\
\hline
\end{tabular}

\subsubsection{Western Europe}

Figure 20 and Figure 21 show the number of detentions and logarithmic cumulative detentions at Paris MoU ports in 2019, by Western European country. All Western European countries have detention records, with the Dutch flag having the highest detention record. However, maximum 7 and minimum 1 detention were recorded. All Western European flags have similar detention numbers.

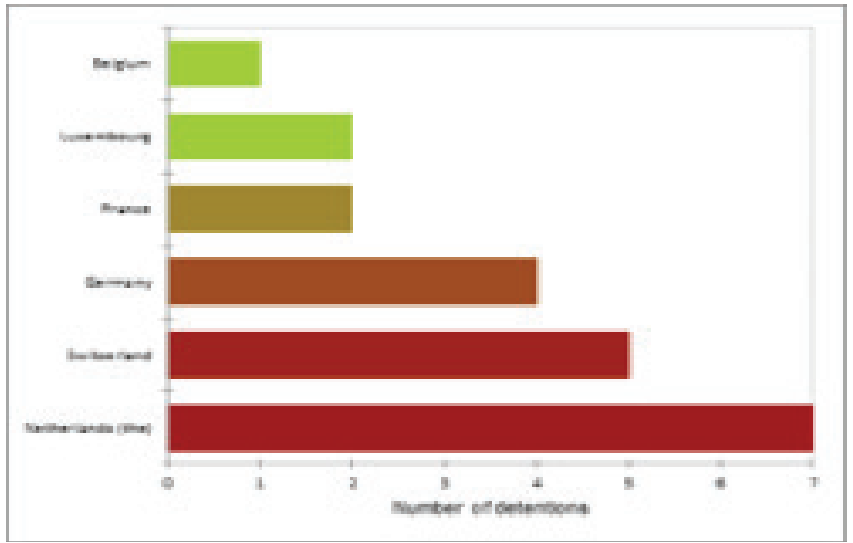

Figure 20.

The highest detention numbers by Western European country in 2019.
According to Figure 21, Dutch flag detentions have been spread throughout the year. German flag detentions have generally occurred in the last quarter of the year, and the opposite is true of Swiss flag detentions. Detentions of vessels sailing under the flags of Belgium, Luxembourg and France have also generally occurred in the second half of the year.

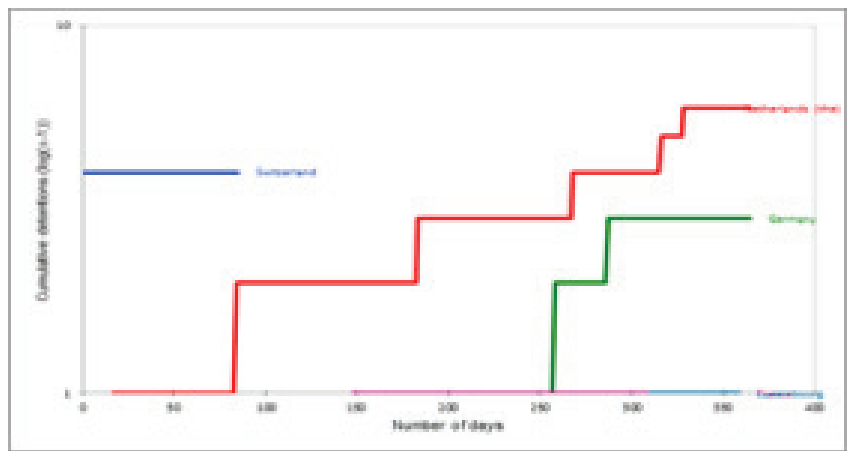

Figure 21.

Cumulative detentions for Western Europe in 2019.

According to Table 15, the highest detention/inspection ratio is 0.23 and belongs to Switzerland. In spite of having the highest number of inspections, the Dutch flag has the lowest detention/inspection ratio. Although German flag has the second highest number of inspections, its detention ratio is not as high. 
Table 15.

Western European regions with the highest detention/inspection ratios.

\begin{tabular}{|c|c|c|c|c|}
\hline No & Country & $\begin{array}{l}\text { Ratio } \\
\text { (Detentions/inspections) }\end{array}$ & Total inspections & Total detentions \\
\hline 1 & Switzerland & 0.23 & 22 & 5 \\
\hline 2 & Luxembourg & 0.03 & 75 & 2 \\
\hline 3 & Germany & 0.02 & 212 & 4 \\
\hline 4 & France & 0.02 & 111 & 2 \\
\hline 5 & Netherlands (the) & 0.01 & 973 & 7 \\
\hline 6 & Belgium & 0.01 & 82 & 1 \\
\hline
\end{tabular}

\subsection{Oceania}

\subsubsection{Melanesia}

Figure 22 shows the number of logarithmic cumulative detentions at Paris MoU ports in 2019, by Melanesian country. Ships of only one Melanesian country, Vanuatu, were inspected under the Paris MoU in 2019. These flag detentions were spread throughout the year, becoming frequent between day 180 and 250.

According to Table 16, Vanuatu flag vessels were inspected 89 times and 8 of them have been detained. Although it was the only flag inspected, almost 1 in 10 of its ships were detained.

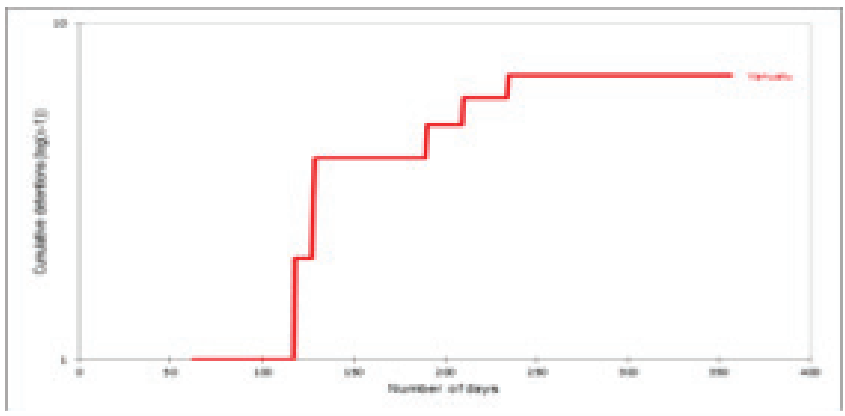

Figure 22.

Cumulative detentions for Melanesia in 2019.

Table 16.

Melanesia regions with the highest detention/inspection ratios.

\begin{tabular}{lllll} 
No & Country & $\begin{array}{l}\text { Ratio } \\
\text { (Detentions/inspections) }\end{array}$ & Total inspections & Total detentions \\
\hline 1 & Vanuatu & 0.09 & 89 & 8 \\
\hline
\end{tabular}

\subsubsection{Micronesia}

Figure 23 and Figure 24 show the number of detentions and logarithmic cumulative detentions at Paris MoU ports in 2019, by Micronesian country. The Marshall Islands flag has by far the highest number of detentions compared to other Micronesian flags. There is no detention record for the Nauru flag. The Palau flag has the second highest number of detentions. Only 3 flags were inspected under the Paris MoU in 2019.
According to Figure 24, Palau flag detentions increased after day 170 , when they became frequent. Marshall Islands flag detentions were frequent until day 250.

According to Table 17, although Marshall Islands flag has the highest number of inspections and detentions compared to other flags, it does not have the highest detention ratio. Despite the Palau flag having less detention than other flags, its ratio is high due to fewer inspections. The Nauru flag had only one inspection at Paris MoU ports. 


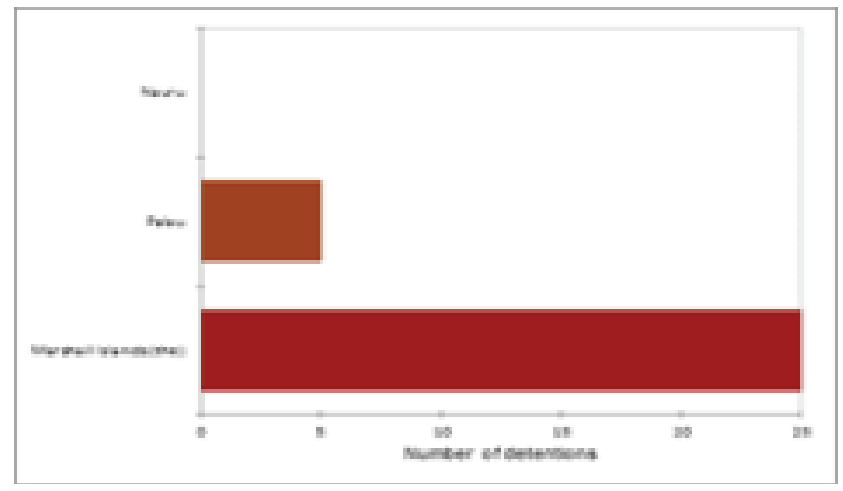

Figure 23.

The highest detention numbers by Micronesian country in 2019.

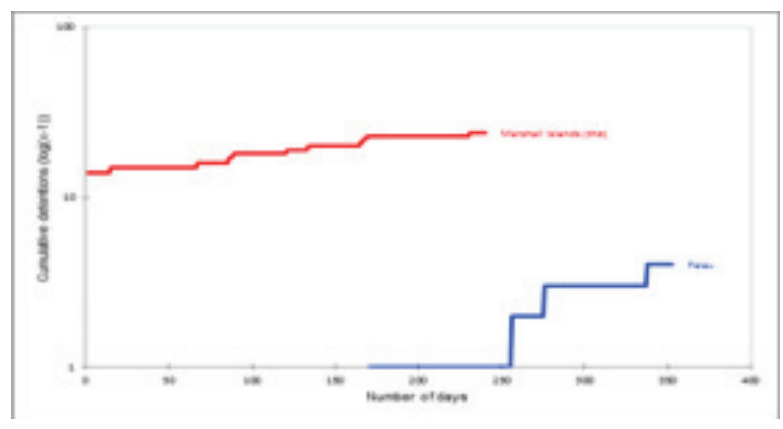

Figure 24.

Cumulative detentions for Micronesia in 2019.

Table 17.

Micronesia regions with the highest detention/inspection ratios.

\begin{tabular}{lllll} 
No & Country & $\begin{array}{l}\text { Ratio } \\
\text { (Detentions/inspections) }\end{array}$ & Total inspections & Total detentions \\
\hline 1 & Palau & 0.08 & 63 & 5 \\
\hline 2 & Marshall Islands (the) & 0.02 & 1568 & 25 \\
\hline 3 & Nauru & 0 & 1 & 0 \\
\hline
\end{tabular}

\subsubsection{Polynesia}

Figure 25 and Figure 26 show the number of detentions and logarithmic cumulative detentions at Paris MoU ports in 2019, by Polynesian country. The number of detentions of ships sailing under the Cook Islands flag far outstrips that of the other Polynesian flags. The flags of Tuvalu and Samoa also have detention records. Niue flag has no detention record. Only 4 flags have been inspected at Paris MoU ports.

Looking at the cumulative distribution in Figure 26, Cook Islands flag detentions have been spread throughout the year but are higher between day 170 and day 360 . The other flags were not accounted for in the cumulative assessment due to having the number of detentions of 1 or less.

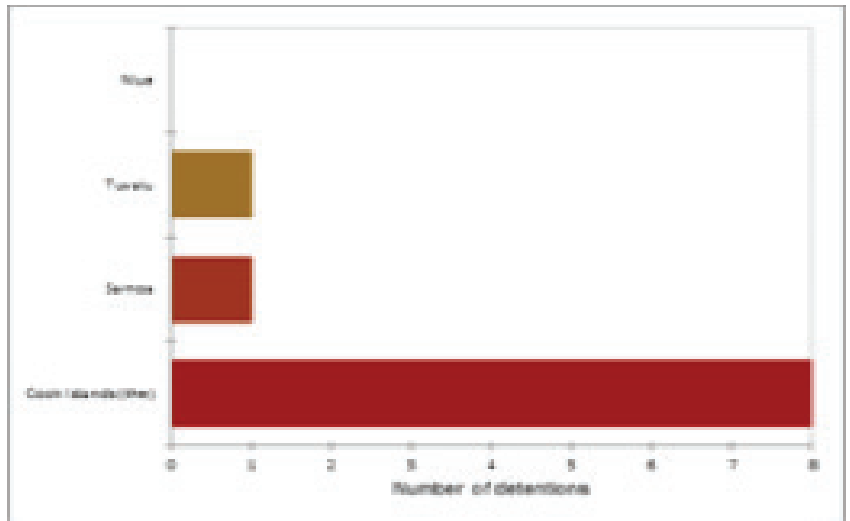

Figure 25.

The highest detention numbers by Polynesian country in 2019. 


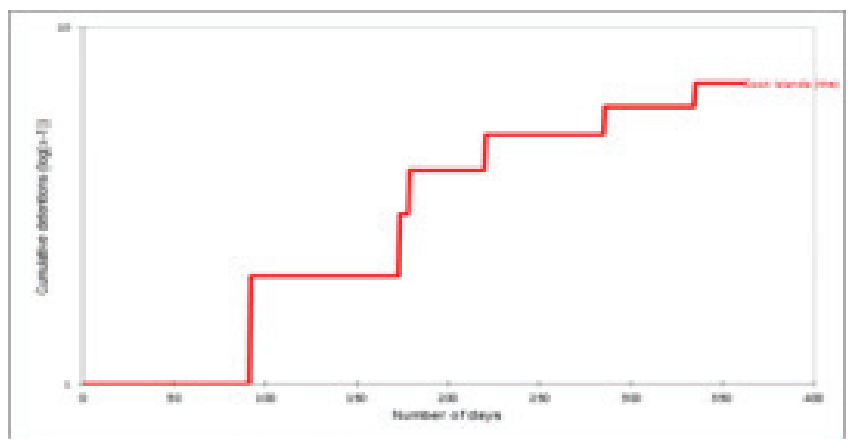

Figure 26.

Cumulative detentions for Polynesia in 2019.
According to Table 18, the highest detention/inspection ratio is 1 and belongs to Samoa. Though the Cook Islands flag had the highest number of inspections and it had the lowest detention/inspection ratio among countries with detentions. There is no clear conclusion for Niue and Samoa since they only had two or fewer inspections.

Table 18.

Polynesian regions with the highest detention/inspection ratios.

\begin{tabular}{lllll} 
No & Country & $\begin{array}{l}\text { Ratio } \\
\text { (Detentions/inspections) }\end{array}$ & Total inspections & Total detentions \\
\hline 1 & Samoa & 1 & 1 & 1 \\
\hline 2 & Tuvalu & 0.11 & 9 & 1 \\
\hline 3 & Cook Islands (the) & 0.07 & 113 & 8 \\
\hline 4 & Niue & 0 & 2 & 0 \\
\hline
\end{tabular}

\section{DISCUSSION}

In this study, cumulative analysis by country was conducted relying on the detention/inspection ratios under the Paris MoU. In this context, the number of inspections and detentions was analyzed for each country individually. In addition, the countries were categorized into geographical regions, as defined by the United Nations.

Comparing the Paris MoU inspections and their results, 17,909 and 17,952 inspections were performed in 2019 and 2018 , respectively. There are clearly no huge differences in the numbers of inspections conducted in these two years. At this point, Covid-19 can be said not to have disrupted the inspection of ships arriving at the ports under the jurisdiction of the Paris MoU in 2019. However, although the onset of the Covid-19 pandemic was in 2019, its effects have been more palpable in 2020 all over the world. At this point, Akyurek and Bolat (2020) stated that although the number of inspections decreased dramatically when COVID-19 hit the European Union, statistics relating to the detention/inspection ratio also indicate that the PSC still works efficiently. 9,320 and 9,368 inspections found deficiencies, there were 529 and 566 detentions, 25 and 24 banns were proclaimed in 2019 and 2018, respectively. Inspections conducted in accordance with the Paris MoU clearly found more deficiencies and more vessels were detained in 2018 than in 2019. However, Paris MoU inspections were denied access more frequently in 2019.

According to results by countries, Panama, Liberia, Malta, and the Marshall Islands had the highest number of inspections in 2019 and 2018. This result can be explained by the fact that these countries also have the largest fleets in the world (UNCTAD, 2020). Panama, Malta and Liberia had the highest number of deficiencies in 2018, while Panama, Liberia and Malta had the highest number of deficiencies in 2019.

The analysis of detention/inspection ratios in Table 19 shows that Samoa had the highest percentage of detentions, which had one inspection and one detention in 2019. On the other hand, Cameroon, Qatar, Switzerland, and Albania, with more than one inspection, had detention rates of $27.4 \%, 25 \%$, $22.7 \%$, and $21.4 \%$ respectively in 2019. In 2018, Honduras and Indonesia had the highest detention/inspection ratio of $33.3 \%$, followed by Jordan and Samoa with $25 \%$. Finally, Tuvalu had the detention/inspection ratio of $20 \%$ in 2018.

According to statistics (Paris MoU, 2018, 2019), while the Isle of Man, the Bahamas, and Singapore (in that order) had the highest rankings in the Paris MoU white list in 2018, the United 
Kingdom, Norway, and the Bahamas ranked highest on the Paris MoU white list in 2019. The Isle of Man and Singapore fell to sixteenth and seventh position, respectively, in 2019. The United Kingdom improved its ranking from fifth to first place in 2019. Saudi Arabia and the United States took up the first two places on the grey list in 2018, with Morocco and Saudi Arabia doing the same in 2019. Morocco improved its position from tenth to first place in 2019. The United States moved up from the grey list and made it to the fortieth place on the white list in 2019. As for the black list, Cook Islands and Belize took the first two places in 2018, and Tunisia and Cook Islands in 2019. These country ranking changes on BGW lists affect regional maps of ship quality.

The map of regions based on detention numbers under the Paris MoU, as seen in Table 20, shows that the region of Polynesia had the highest detention/inspection ratio in 2019 (0.30), followed by the region of Sub-Saharan Africa with the 0.18 ratio. Eastern Europe and Melanesia had a 0.09 detention/inspection ratio under the Paris MoU inspections in 2019. Northern Africa scored 0.98 and Latin America and the Caribbean 0.07. On the other hand, there are no detention results under the Paris MoU inspections for Northern America and Central Asia. In this context, it can be said that ships flying flags from the Polynesian region are subject to further inspection under the Paris MoU and are generally considered high risk. Ships flying flags from the regions of Northern America and Central Asia are generally considered low-risk ships, as they are more compliant with international rules even under COVID-19.

Table 19.

Summary of detention/inspection figures by regions.

Sub-Saharan Africa

\begin{tabular}{|c|c|c|c|c|}
\hline No & Country & $\begin{array}{l}\text { Ratio } \\
\text { (Detentions/inspections) }\end{array}$ & Total inspections & Total detentions \\
\hline 1 & Nigeria & 1 & 1 & 1 \\
\hline 2 & Cameroon & 0.28 & 18 & 5 \\
\hline 3 & Comoros (the) & 0.17 & 127 & 21 \\
\hline 4 & Togo & 0.15 & 151 & 22 \\
\hline 5 & $\begin{array}{l}\text { Tanzania, the United } \\
\text { Republic of }\end{array}$ & 0.11 & 92 & 10 \\
\hline 6 & Sierra Leone & 0.07 & 124 & 9 \\
\hline 7 & Liberia & 0.02 & 1472 & 35 \\
\hline 8 & Cabo Verde & 0 & 1 & 0 \\
\hline 9 & Ethiopia & 0 & 1 & 0 \\
\hline 10 & Mauritius & 0 & 5 & 0 \\
\hline \multicolumn{5}{|c|}{ Northern Africa } \\
\hline 11 & Egypt & 0.17 & 18 & 3 \\
\hline 12 & Tunisia & 0.17 & 12 & 2 \\
\hline 13 & Algeria & 0.04 & 27 & 1 \\
\hline 14 & Libya & 0 & 10 & 0 \\
\hline 15 & Morocco & 0 & 18 & 0 \\
\hline \multicolumn{5}{|c|}{ Latin America and the Caribbean } \\
\hline 16 & Dominican Republic & 0.17 & 6 & 1 \\
\hline 17 & Jamaica & 0.14 & 7 & 1 \\
\hline 18 & Belize & 0.11 & 99 & 11 \\
\hline 19 & $\begin{array}{l}\text { Saint Vincent and the } \\
\text { Grenadines }\end{array}$ & 0.09 & 141 & 12 \\
\hline
\end{tabular}




\begin{tabular}{|c|c|c|c|c|}
\hline 20 & Saint Kitts and Nevis & 0.09 & 33 & 3 \\
\hline 21 & Panama & 0.05 & 2026 & 92 \\
\hline 22 & Antigua and Barbuda & 0.02 & 714 & 16 \\
\hline 23 & Bahamas (the) & 0.01 & 676 & 8 \\
\hline 24 & Barbados & 0.01 & 143 & 2 \\
\hline 25 & Cayman Islands (the) & 0.01 & 148 & 2 \\
\hline \multicolumn{5}{|c|}{ Northern America } \\
\hline 26 & Bermuda & 0 & 72 & 0 \\
\hline 27 & Canada & 0 & 5 & 0 \\
\hline 28 & $\begin{array}{l}\text { United States of America } \\
\text { (the) }\end{array}$ & 0 & 0 & 0 \\
\hline \multicolumn{5}{|c|}{ Central Asia } \\
\hline 29 & Kazakhstan & 0 & 14 & 0 \\
\hline 30 & Turkmenistan & 0 & 3 & 0 \\
\hline \multicolumn{5}{|c|}{ Eastern Asia } \\
\hline 31 & Mongolia & 0,13 & 23 & 3 \\
\hline 32 & China & 0,05 & 44 & 2 \\
\hline 33 & Philippines (the) & 0,04 & 49 & 2 \\
\hline 34 & Korea (the Republic of) & 0,04 & 24 & 1 \\
\hline 35 & Singapore & 0,02 & 696 & 14 \\
\hline 36 & Hong Kong (China) & 0,02 & 642 & 12 \\
\hline 37 & Indonesia & 0 & 1 & 0 \\
\hline 38 & Japan & 0 & 64 & 0 \\
\hline 39 & Malaysia & 0 & 10 & 0 \\
\hline 40 & Taiwan (Province of China) & 0 & 7 & 0 \\
\hline \multicolumn{5}{|c|}{ Southern Asia } \\
\hline 41 & Bangladesh & 0.17 & 6 & 1 \\
\hline 42 & Iran (Islamic Republic of) & 0.03 & 35 & 1 \\
\hline 43 & India & 0 & 15 & 0 \\
\hline 44 & Pakistan & 0 & 1 & 0 \\
\hline 45 & Sri Lanka & 0 & 6 & 0 \\
\hline \multicolumn{5}{|c|}{ Western Asia } \\
\hline 46 & Qatar & 0.25 & 8 & 2 \\
\hline 47 & Lebanon & 0.08 & 26 & 2 \\
\hline 48 & Cyprus & 0.03 & 726 & 20 \\
\hline 49 & Turkey & 0.02 & 252 & 4 \\
\hline 50 & Azerbaijan & 0 & 24 & 0 \\
\hline 51 & Georgia & 0 & 4 & 0 \\
\hline 52 & Israel & 0 & 8 & 0 \\
\hline 53 & Jordan & 0 & 1 & 0 \\
\hline
\end{tabular}




\begin{tabular}{|c|c|c|c|c|}
\hline 54 & Kuwait & 0 & 5 & 0 \\
\hline 55 & Saudi Arabia & 0 & 16 & 0 \\
\hline \multicolumn{5}{|c|}{ Eastern Europe } \\
\hline 56 & Moldova (the Republic of) & 0.15 & 131 & 20 \\
\hline 57 & Bulgaria & 0.13 & 8 & 1 \\
\hline 58 & Ukraine & 0.12 & 34 & 4 \\
\hline 59 & Poland & 0.1 & 29 & 3 \\
\hline 60 & Russian Federation (the) & 0.03 & 425 & 12 \\
\hline 61 & Romania & 0 & 1 & 0 \\
\hline \multicolumn{5}{|c|}{ Northern Europe } \\
\hline 62 & Estonia & 0.03 & 31 & 1 \\
\hline 63 & $\begin{array}{l}\text { United Kingdom of Great } \\
\text { Britain and Northern } \\
\text { Ireland }\end{array}$ & 0.02 & 397 & 7 \\
\hline 64 & Isle of Man & 0.02 & 204 & 5 \\
\hline 65 & Finland & 0.02 & 158 & 3 \\
\hline 66 & Faroe Islands & 0.02 & 91 & 2 \\
\hline 67 & Sweden & 0.02 & 112 & 2 \\
\hline 68 & Ireland & 0.02 & 53 & 1 \\
\hline 69 & Norway & 0.01 & 597 & 5 \\
\hline 70 & Denmark & 0 & 469 & 2 \\
\hline 71 & Iceland & 0 & 1 & 0 \\
\hline \multicolumn{5}{|c|}{ Southern Europe } \\
\hline 72 & Albania & 0.21 & 28 & 6 \\
\hline 73 & Portugal & 0.03 & 402 & 11 \\
\hline 74 & Gibraltar, UK & 0.03 & 226 & 7 \\
\hline 75 & Malta & 0.02 & 1507 & 31 \\
\hline 76 & Italy & 0.02 & 348 & 7 \\
\hline 77 & Greece & 0.02 & 250 & 6 \\
\hline 78 & Spain & 0.02 & 55 & 1 \\
\hline 79 & Croatia & 0 & 34 & 0 \\
\hline 80 & Montenegro & 0 & 3 & 0 \\
\hline 81 & Slovenia & 0 & 3 & 0 \\
\hline \multicolumn{5}{|c|}{ Western Europe } \\
\hline 82 & Switzerland & 0.23 & 22 & 5 \\
\hline 83 & Luxembourg & 0.03 & 75 & 2 \\
\hline 84 & Germany & 0.02 & 212 & 4 \\
\hline 85 & France & 0.02 & 111 & 2 \\
\hline 86 & Netherlands (the) & 0.01 & 973 & 7 \\
\hline 87 & Belgium & 0.01 & 82 & 1 \\
\hline
\end{tabular}




\section{REFERENCES}

Akyurek, E. \& Bolat, P., 2020. Port state control at European Union under pandemic outbreak. European Transport Research Review, 12(1). Available at: http://dx.doi.org/10.1186/s12544-020-00460-4.

Bang, H.-S. \& Jang, D.-J., 2012. Recent Developments in Regional Memorandums of Understanding on Port State Control. Ocean Development \& International Law, 43(2), pp.170-187. Available at: http://dx.doi.org/10.1080/00908320.2012.672293.

Bijwaard, G.E. \& Knapp, S., 2009. Analysis of ship life cycles-The impact of economic cycles and ship inspections. Marine Policy, 33(2), pp.350-369. Available at: http://dx.doi.org/10.1016/j.marpol.2008.08.003.

Bolat, F., 2019. Investigation of Performances of Turkish Flagged Ships in the Tokyo Memorandum of Understanding, Avrasya Uluslararası Araştırmalar Dergisi, 7(19), pp. 468-487.

Cariou, P., Mejia, M.Q. \& Wolff, F.-C., 2008. On the effectiveness of port state control inspections. Transportation Research Part E: Logistics and Transportation Review, 44(3), pp.491-503. Available at: http://dx.doi.org/10.1016/j.tre.2006.11.005.

Chen, J. et al., 2017. The development of ship registration policy in China: Response to flags of convenience. Marine Policy, 83, pp.22-28. Available at: http://dx.doi.org/10.1016/j.marpol.2017.05.020.

Corres, A. J. E., \& Pallis, A. A., 2008. Flag State Performance: An Empirical Analysis. WMU Journal of Maritime Affairs, 7(1), pp. 241-261. Available at: https://doi.org/10.1007/BF03195134.

Doumbia-Henry, C., 2020. Shipping and COVID-19: Protecting Seafarers as Frontline Workers, WMU Journal of Maritime Affairs, 19(3), pp. 279-293. Available at: https://doi.org/10.1007/s13437-020-00217-9.

EMSA THETIS, 2020. Database. Available at: https://portal.emsa.europa.eu/web/ thetis/inspections.

Fuwape, I. A., Okpalaonwuka, C. T., \& Ogunjo, S. T., 2021. Impact of COVID -19 Pandemic Lockdown on Distribution of Inorganic Pollutants in Selected Cities of Nigeria, Air Quality, Atmosphere \& Health, 14(2), pp. 149-155. Available at: https://doi.org/10.1007/s11869-020-00921-8.

Knapp, S., \& Franses, P. H., 2007a. Econometric Analysis on The Effect of Port State Control Inspections on The Probability of Casualty, Can Targeting of Substandard Ships For Inspections Be Improved?, Marine Policy, 31(4), pp. 550-563. Available at: https://doi.org/10.1016/j.marpol.2006.11.004.

Knapp, S., \& Franses, P. H., 2007b. A Global View on Port State Control: Econometric Analysis of The Differences Across Port State Control Regimes, Maritime Policy \& Management, 34(5), pp. 453-483. Available at: https://doi.org/10.1080/03088830701585217.

Knapp, S., \& Franses, P. H., 2008. Econometric Analysis to Differentiate Effects of Various Ship Safety Inspections, Marine Policy, 32(4), pp. 653-662. Available at: https://doi.org/10.1016/j.marpol.2007.11.006.

Knapp, S., \& Franses, P. H., 2010. Comprehensive Review of the Maritime Safety Regimes: Present Status and Recommendations for Improvements, Transport Reviews, 30(2), pp. 241-270. Available at: https://doi.org/10.1080/01441640902985934.
Knapp, S., \& van de Velden, M., 2009. Visualization of Differences in Treatment of Safety Inspections across Port State Control Regimes: A Case for Increased Harmonization Efforts, Transport Reviews, 29(4), pp. 499-514. Available at: https://doi.org/10.1080/01441640802573749.

Li, K. X., Yin, J., \& Fan, L., 2014. Ship Safety Index, Transportation Research Part A: Policy and Practice, 66(1), pp. 75-8. Available at: https://doi.org/10.1016/j.tra.2014.04.016.

Li, K. X., \& Zheng, H., 2008. Enforcement of Law by the Port State Control (PSC), Maritime Policy \& Management, 35(1), pp. 61-71. Available at: https://doi.org/10.1080/03088830701848912.

Mansell, J. N. K., 2009. Flag State Responsibility: Historical Development and Contemporary Issues, In Flag State Responsibility: Historical Development and Contemporary Issues. Available at: https://doi.org/10.1007/978-3-540-92933-8.

Paris MoU, 2018. Port State Control Annual Report 2018. Available at: https://www. parismou.org/2018-paris-mou-annual-report-consistent-compliance.

Paris MoU, 2019. Port State Progression Detention Rate Down Annual Report 2019. Available at: https://www.parismou.org/2019-paris-mou-annual-report-port-stateprogression-detention-rate-down.

Paris MoU, 2020a. Paris MoU Guidance On Covid-19 Updated And Available For The Industry. Available at: https://www.parismou.org/paris-mou-covid-19-publications.

Paris MoU, 2020b. Paris MoU Statistics and Current List. Available at: https://www. parismou.org/detentions-banning/white-grey-and-black-list.

Perepelkin, M., Knapp, S., Perepelkin, G., \& de Pooter, M., 2010. An Improved Methodology to Measure Flag Performance for The Shipping Industry, Marine Policy, 34(3), pp. 395-405. Available at: https://doi.org/10.1016/j.marpol.2009.09.002.

Ravira, F. J., \& Piniella, F., 2016. Evaluating The Impact of PSC Inspectors' Professional Profile: A Case Study of the Spanish Maritime Administration, WMU Journal of Maritime Affairs, 15(2), pp. 221-236. Available at: https://doi.org/10.1007/s13437-015-0096-y.

Rodríguez, E., \& Piniella, F., 2012. The New Inspection Regime of The Paris Mou on Port State Control: Improvement of the System, Journal of Maritime Research, 9(1), pp. 9-16.

UNCTAD, 2020. Merchand Fleet. Available at: https://stats.unctad.org/handbook/ MaritimeTransport/MerchantFleet.html.

United Nations, 2019. World Population Prospects 2019. Available at: https:// population.un.org/wpp/DefinitionOfRegions/\#: :text=Geographic regions\%3A countries and areas, \%3B Northern America\%2C and Oceania.

Wu, J., Jin, Y., \& Fu, J., 2014. Effectiveness Evaluation on Fire Drills for Emergency and PSC Inspections on Board, TransNav, the International Journal on Marine Navigation and Safety of Sea Transportation, 8(2), pp. 229-236. Available at: https://doi.org/10.12716/1001.08.02.08

XLSTAT, 2020. XLSTAT, Available at: https://help.xlstat.com/s/article/covid-19-dataanalysis-in-excel?language=en US.

Yang, Z., Yang, Z., \& Teixeira, A. P., (2020), Comparative Analysis of The Impact of New Inspection Regime on Port State Control Inspection, Transport Policy, 92, pp. 65-80. Available at:

https://doi.org/10.1016/j.tranpol.2020.04.009. 